\title{
Child Marriage: the Unspoken Consequence of COVID-19
}

\author{
Efa Nugroho ${ }^{1}, \mathrm{Najib}^{2}$, Mugia Bayu Rahardja ${ }^{3}$ \\ \{efa.nugroho@mail.unnes.ac.id ${ }^{1}$,jibpenkb@gmail.com², raharja82@gmail.com ${ }^{3}$ \} \\ Universitas Negeri Semarang, Indonesia ${ }^{1}$ \\ Badan Kependudukan dan Keluarga Berencana Nasional of Central Java, Indonesia ${ }^{2}$ \\ Research Center for Population Research, Badan Kependudukan dan Keluarga Berencana Nasional, \\ Indonesia ${ }^{3}$
}

\begin{abstract}
Covid-19 has had a major negative impact on the lives. One of them is an additional 10 million child marriages this decade. An increase in the number of child marriages has also occurred in Indonesia. This study used the 2017 IDHS data. To strengthen the study, references from relevant journal articles were also added. In Indonesia, the provinces with the highest percentage of teenage marriage aged 10-14 years were Central Java (52.1\%), South Kalimantan (9\%), West Java (7.5\%), while the provinces with the highest percentage of cases of teenage marriage aged 15-19 years were Central Kalimantan (52.1\%), West Java (50.2\%), and South Kalimantan (48.4\%). Child marriage has jumped up to 300 percent during the COVID-19 pandemic. Child marriage were due to differences in knowledge, education, economy and culture factors in various regions in Indonesia.
\end{abstract}

Keywords: Indonesia, teenage marriage, culture, Covid-19.

\section{Introduction}

Child marriage is nothing new. Over the next decade, according to Unicef, there will be more than 10 million new girls who have the potential to become brides at a very young age. Before the pandemic rolled around, estimated that around 100 million children were undergoing forced marriages over the next 10 years.

Article 7 paragraph [1] of Law Number 1 Year 1974 states that marriage is only permitted if the male party reaches the age of 19 (nineteen) years and the woman has reached the age of 16 (sixteen) years, this provision allows for child marriage in female children because in Article 1 point 1 of the Law on Amendments to Law Number 23 of 2002 concerning Child Protection it is defined that a child is someone who has not reached the age of 18 (eighteen) years, including children who are still in the womb.

Indonesia is the 37 th country with a high rate of young marriages, according to the United Nations Development Economic and Social Affairs, and the second highest in ASEAN after Cambodia. Basic Health Research Data (RISKESDAS) in 2013 shows that, the growth process is still ongoing until the age of 18 years, the age of the youngest menarche, especially those aged 6-12 years, needs special attention not to get married. The age at first marriage at the age of 10-14 years in Indonesia is quite high, namely $4.8 \%$ and at the age of $15-19$ years is $41.9 \%$. Even births in the last five years before this observation were carried out, had occurred in 0.3 
per 1000 women aged 10-14 years, and 53.9 per 1000 women aged 15-19 years. The age at first marriage at a very young age (10-14 years) tends to be higher in rural areas (6.2\%), and among women who do not attend school (9.5\%), farmers/ fishermen / laborers (6.3\%), as well as the lowest economic status $(6.0 \%)$ [1].

In Indonesia, the provinces with the highest percentage of early marriage aged 10-14 years are Central Java (52.1\%), South Kalimantan (9\%), West Java (7.5\%), East Kalimantan and Central Kalimantan respectively (7\%), and Banten $(6.5 \%)$ while the provinces with the highest percentage of early marriage cases aged 15-19 years were Central Kalimantan $(52.1 \%)$, West Java (50.2\%), South Kalimantan (48.4\%), Bangka Belitung (47.9\%), and Central Sulawesi $(46.3 \%)[1]$.

According to the BKKBN child marriage has reached 20\% [2]. In addition, the Covid-19 pandemic has brought new problems with the increasing number of early marriages in Indonesia. In January-June 2020, 34,000 applications for early marriage dispensation (under 19 years) were submitted, $97 \%$ of which were granted. Even though throughout 2019, there were only 23,700 requests.

This study aimed to describe the distribution of the number of child marriage partners and the determinant factors based on the analysis of the 2017 IDHS data. This study also provides an overview of trends in child marriage during the Covid-19 pandemic.

\section{Methods}

This study uses data from the 2017 Indonesian Demographic and Health Survey (IDHS)2. The 2017 IDHS is a survey conducted jointly by the Central Statistics Agency (BPS), the National Population and Family Planning Agency (BKKBN), and the Ministry of Health (MoH). Data collection took place from 24 July to 30 September 2017. Funding for the survey was provided by the Government of Indonesia. In technical implementation, the Indonesian Government is assisted by ICF through the Demographic and Health Surveys (DHS) Program, namely the United States Agency for International Development (USAID) program that provides funding and technical assistance in the implementation of population and health surveys in many countries. The main objective of the 2017 IDHS is to provide updated estimates of basic demographic and health indicators. The 2017 IDHS provides a comprehensive picture of the population and health of mothers and children in Indonesia [2].

The 2017 IDHS sampling design is designed to be able to present national and provincial level estimates. The 2017 IDHS sample includes 1,970 census blocks covering urban and rural areas. It is hoped that the number of census blocks will be able to obtain a total sample of 49,250 households. From the entire household sample, it is expected that around 59,100 female respondents of childbearing age aged 15-49, 24,625 male respondents aged 15-24, and 14,193 married male respondents aged 15-54 can be obtained. The sample frame for the 2017 IDHS uses the Census Block Master Sample from the 2010 Population Census (SP2010). Meanwhile, the sample frame for selecting households uses the regular household list as a result of updating the households from the selected census block. This list of ordinary households does not include special households such as orphanages, police / military barracks, prisons, and boarding houses where there are at least 10 people boarding a boarding house with meals.

The 2017 IDHS employed a stratified two-stage sample approach, with Stage 1 picking a number of census blocks using a systematic probability proportional to size (PPS) with the number of households listed in SP2010. In this scenario, an implicit stratification procedure 
based on urban and rural areas was used, as well as sorting census blocks based on the Wealth Index category from the SP2010 findings. Stage 2 involves carefully picking 25 ordinary households in each census block from the results of updating the households in each census block. The sample of married males (PK) will be chosen systematically from the 25 families by 8 houses. The women of childbearing age couples who were married between the ages of 15 and 24 were the subjects of this study, with a total of 13401 respondents. The research findings are described using descriptive data analysis. The information is presented in the form of graphs and tables.

This study also uses various journal article references to provide an overview of the trend of child marriage during the Covid-19 pandemic.

\section{Results}

In recent years, the world has been working to reduce the rate of child marriage 11,12. However, it turns out that with the Cocvid-19 pandemic there will be an increase in the number of child marriages. Prior to the Covid-19 pandemic, it was estimated that around 100 million children were undergoing forced marriages for the next 10 years. This figure is now estimated to increase to $10 \%$. Over the next decade, there will be more than 10 million new girls who have the potential to become brides at a very young age. Closing schools, declining economic conditions and hampering assistance for affected families increase the potential for girls to become wives before they reach adulthood in 2030 .

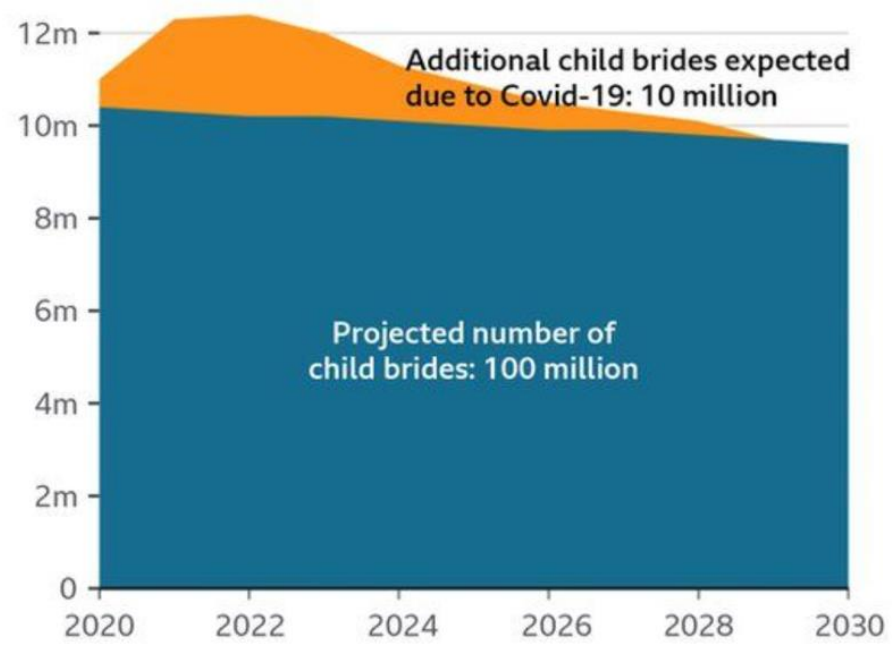

Fig. 1. Prediction of an increase in the number of child marriage in the world during a pandemic

Legally, child marriage is legalized by Law Number 1 in 1974 of Republic Indonesia concerning Marriage. The law allows girls aged 16 to marry, as stated in article 7 paragraph 1, "Marriage is only permitted if the male has reached 19 (nineteen) years, and the woman has reached 16 (sixteen) years." Meanwhile, Article 26 of Law No. 23/2002 on Child Protection, 
states that parents are required to protect children from early marriage. However, this article, as with the Marriage Law, is without the existence of a criminal sanction provision so that this provision is almost meaningless in protecting children from the threat of early marriage. Weak supervision and law enforcement in Indonesia, provides an opening for anyone, including parents, government officials, certain groups and communities to falsify population documents, especially age-related, so that marriage can be prohibited. It is not surprising that it is often found that many girls are married off at the age of under 16. Based on the analysis of research data, it is found that early marriage rates in Indonesia are shown in Figure 1:

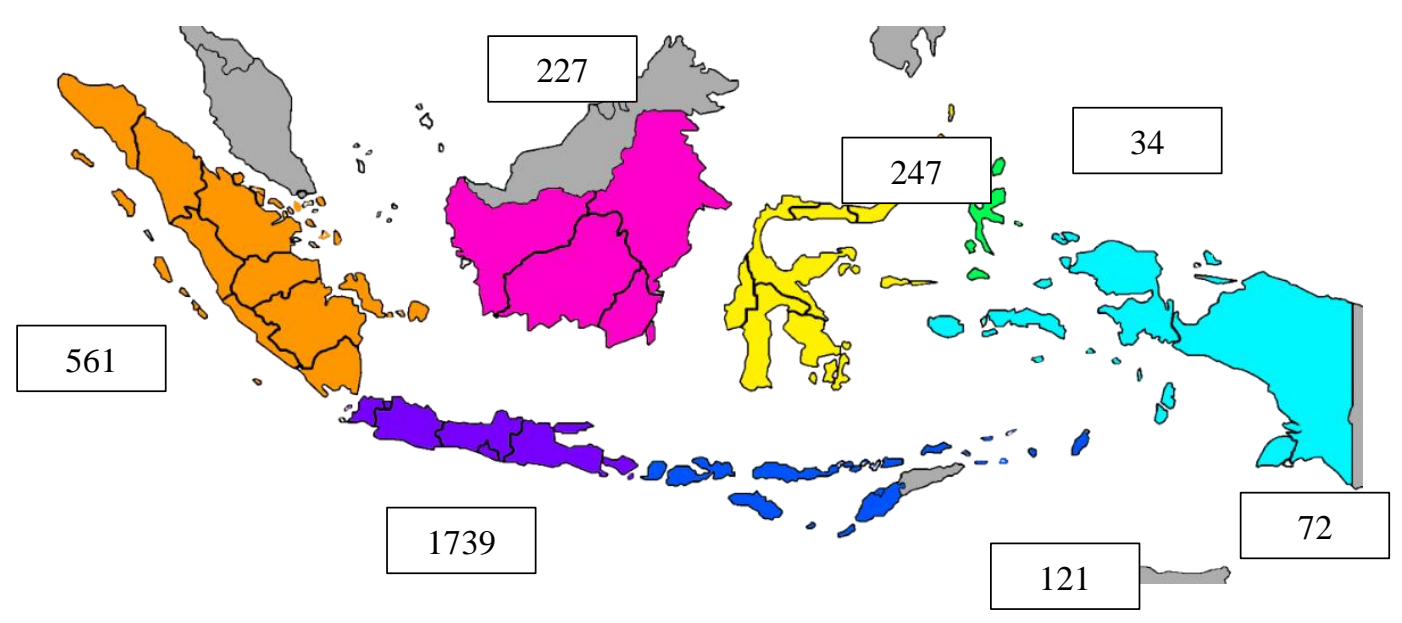

Fig. 1. Distribution of the number of respondents who engaged in child marriage

Early marriage in Indonesia is motivated by many factors, such as the low economic level of the family, low education, and pregnancy outside of marriage. Developed cultural and religious values are also a driving factor for early marriage. 
Table 1. Description table

\begin{tabular}{|c|c|c|c|c|c|c|c|c|c|c|c|c|c|c|}
\hline & \multicolumn{2}{|c|}{ Sumatera } & \multicolumn{2}{|c|}{ Java-Bali } & \multicolumn{2}{|c|}{$\begin{array}{c}\text { Nusa } \\
\text { Tenggara }\end{array}$} & \multicolumn{2}{|c|}{$\begin{array}{c}\text { Kalimanta } \\
n\end{array}$} & \multicolumn{2}{|c|}{ Sulawesi } & \multirow{2}{*}{$\begin{array}{c}\text { Malu } \\
\mathrm{ku} \\
\mathrm{n}\end{array}$} & \multicolumn{2}{|c|}{ Papua } & \multirow[b]{2}{*}{$\%$} \\
\hline & $\mathrm{n}$ & $\%$ & $\mathrm{n}$ & $\%$ & $\mathrm{n}$ & $\%$ & $\mathrm{n}$ & $\%$ & $\mathrm{n}$ & $\%$ & & $\%$ & $\mathrm{n}$ & \\
\hline \multicolumn{15}{|l|}{$\begin{array}{l}\text { Teenage } \\
\text { Marriage }\end{array}$} \\
\hline 1. Yes & $\begin{array}{r}56 \\
1\end{array}$ & $\begin{array}{r}18, \\
7\end{array}$ & 1739 & 57,9 & 121 & 4,0 & 227 & 7,6 & 247 & 8,2 & 34 & 1,1 & 72 & 2,4 \\
\hline 2. No & $\begin{array}{l}24 \\
84 \\
\end{array}$ & $\begin{array}{r}22, \\
2 \\
\end{array}$ & 6578 & 58,7 & 449 & 4,0 & 588 & 5,2 & 816 & 7,3 & 141 & 1,3 & 158 & 1,4 \\
\hline $\begin{array}{l}\text { Socio } \\
\text { Economic } \\
\text { Status }\end{array}$ & & & & & & & & & & & & & & \\
\hline 1. Lowest & $\begin{array}{r}63 \\
3\end{array}$ & $\begin{array}{r}26, \\
3\end{array}$ & 752 & 31,3 & 274 & $\begin{array}{r}11, \\
4\end{array}$ & 204 & 8,5 & 310 & $\begin{array}{r}12, \\
9\end{array}$ & 88 & 3,7 & 143 & 5,9 \\
\hline $\begin{array}{l}\text { 2. Middle } \\
\text { to Low }\end{array}$ & $\begin{array}{r}71 \\
9\end{array}$ & $\begin{array}{r}25 \\
4\end{array}$ & 1466 & 51,8 & 125 & 4,4 & 190 & 6,7 & 256 & 9,1 & 38 & 1,4 & 35 & 1,2 \\
\hline 3. Middle & $\begin{array}{r}65 \\
7\end{array}$ & $\begin{array}{r}22, \\
2\end{array}$ & 1832 & 62,0 & 64 & 2,2 & 177 & 6,0 & 180 & 6,1 & 23 & 0,8 & 20 & 0,7 \\
\hline $\begin{array}{l}\text { 4. Middle } \\
\text { to high }\end{array}$ & $\begin{array}{r}58 \\
4\end{array}$ & $\begin{array}{r}19 \\
8\end{array}$ & 2000 & 67,8 & 53 & 1,8 & 131 & 4,4 & 151 & 5,1 & 16 & 0,5 & 16 & 0,5 \\
\hline $\begin{array}{l}\text { 5. Highes } \\
\mathrm{t}\end{array}$ & $\begin{array}{r}45 \\
3 \\
\end{array}$ & $\begin{array}{r}14 \\
7 \\
\end{array}$ & 2266 & 73,6 & 53 & 1,7 & 114 & 3,7 & 166 & 5,4 & 9 & 0,3 & 18 & 0,6 \\
\hline \multicolumn{15}{|l|}{ Education } \\
\hline $\begin{array}{l}\text { 1. No } \\
\text { School }\end{array}$ & 9 & $\begin{array}{r}15 \\
5\end{array}$ & 10 & 17,1 & 3 & 5,4 & 4 & 6,7 & 6 & $\begin{array}{r}10, \\
9\end{array}$ & 1 & 0,8 & 26 & $\begin{array}{r}43, \\
5\end{array}$ \\
\hline $\begin{array}{l}\text { 2. Elemen } \\
\text { tary } \\
\text { School }\end{array}$ & $\begin{array}{r}24 \\
6\end{array}$ & $\begin{array}{r}20 \\
8\end{array}$ & 664 & 56,1 & 46 & 3,9 & 111 & 9,4 & 76 & 6,4 & 11 & 0,9 & 30 & 2,5 \\
\hline $\begin{array}{ll}\text { 3. High } \\
\text { School }\end{array}$ & $\begin{array}{l}21 \\
92\end{array}$ & $\begin{array}{r}21, \\
3\end{array}$ & 6171 & 59,9 & 406 & 3,9 & 566 & 5,5 & 707 & 6,9 & 116 & 1,1 & 143 & 1,4 \\
\hline $\begin{array}{l}\text { 4. Collag } \\
\mathrm{e}\end{array}$ & $\begin{array}{r}59 \\
9 \\
\end{array}$ & $\begin{array}{r}22 \\
4 \\
\end{array}$ & 1472 & 55,0 & 114 & 4,3 & 135 & 5,1 & 275 & $\begin{array}{r}10, \\
3 \\
\end{array}$ & 48 & 1,8 & 32 & 1,2 \\
\hline \multicolumn{15}{|l|}{$\begin{array}{l}\text { Working } \\
\text { Status }\end{array}$} \\
\hline 1. Work & $\begin{array}{l}11 \\
02\end{array}$ & $\begin{array}{r}22, \\
1\end{array}$ & 3002 & 60,2 & 152 & 3,0 & 293 & 5,9 & 310 & 6,2 & 41 & 0,8 & 85 & 1,7 \\
\hline $\begin{array}{l}\text { 2. Doesn' } \\
\text { t work }\end{array}$ & $\begin{array}{l}19 \\
44 \\
\end{array}$ & $\begin{array}{r}21, \\
1\end{array}$ & 5315 & 57,6 & 418 & 4,5 & 522 & 5,7 & 753 & 8,2 & 133 & 1,4 & 146 & 1,6 \\
\hline \multicolumn{15}{|l|}{ Residence } \\
\hline 1. Urban & $\begin{array}{l}12 \\
55\end{array}$ & $\begin{array}{r}16, \\
5\end{array}$ & 5279 & 69,3 & 201 & 2,6 & 349 & 4,6 & 411 & 5,4 & 74 & 1,0 & 49 & 0,6 \\
\hline 2. Rural & $\begin{array}{l}17 \\
91 \\
\end{array}$ & $\begin{array}{r}27, \\
1 \\
\end{array}$ & 3038 & 46,0 & 369 & 5,6 & 467 & 7,1 & 652 & 9,9 & 101 & 1,5 & 181 & 2,8 \\
\hline
\end{tabular}

\section{Discussion}

There are a number of factors that have led to cases of child marriage during the Corona Virus pandemic (Covid-19). Challenges and driving factors for child marriage, especially during the Covid-19 pandemic, that we need to tackle together, namely, one, socio-cultural factors, the 
view that marriage can prevent adultery and to maintain the good name of the family. The next factor, is the economic problem as a result of the pandemic. Parents who have lost their livelihoods see their children as an economic burden, so marrying them off can be a solution. Third, social restrictions and a learning system from home reduce children's activities and limited reproductive health services for adolescents. Fourth, face-to-face counseling services are limited, on the other hand, online or online counseling is not optimal15. The next factor is that the use of the internet for learning from home can increase the risk of cyber violence and children's exposure to pornographic content. The six factors are influencers who marry young and the seventh, there is no agreement between sectors in providing recommendations on applications for marriage dispensation.

Risky Sex Behavior and lack of understanding of adolescent reproductive health education. Adolescents who experimented with sexual behavior while dating their partners was discovered to be the cause. Adolescents are locked in a circle that is difficult to escape due to the lack of openness in reproductive health education, which is still considered a taboo topic [3].

One of the causes of child marriage, which was discovered in eight research areas, is economic motives motivated by poverty. In most cases, this element arises as a result of matching or students dropping out of school due to financial constraints. Another problem of poverty is parents who seek work outside their area and leave their children without sufficient knowledge and education so that their children seek knowledge and understanding in other places [4].

Cultural elements, such as traditions, practices, and religion, are another factor that leads to child marriage. Information about reproductive health is considered taboo, obscene, and evil. It was found that the assumption of child marriage is one of the right solutions for unwanted pregnancies and avoiding sins, as well as the "talk" of society regarding the status of children born later. There were several cases where they were mated since they were young, and when it was considered final, they were married off. Usually the role of parents is very dominant, and they are afraid to refuse the application because it will make it difficult for the child to mate later, so it becomes an excuse to marry off the child at a young age [5].

The factors have done a biological relationship. Namely adolescents who have had a biological relationship like husband and wife. With this condition, the parents of girls tend to immediately marry off their children, because according to the parents of this girl, because they are no longer virgins, this is a disgrace [5], [6].

Education a person who marries, especially at a young age, will certainly have various impacts, especially in the world of education which is vulnerable to economic sustainability, someone who gets married when he just graduated from junior high school or high school, of course his desire to continue school again or take a more education. Girls who marry before the age of 18 are four times less likely to complete secondary education or equivalent (UNICEF).

Child marriage has an impact on the likelihood of divorce and adultery among newly married young couples from a social standpoint [5]. This is due to the fact that emotions are still unstable, making it easier to fight even in the face of minor issues. Because of an unequal relationship, quarrels can sometimes develop to domestic violence/sexual violence, which is particularly common among women [7], [8].

Health consequences (Reproductive and Sexual) Married young people run the risk of not being ready to give birth and care for children, and if they do have an abortion, it could be an unsafe one, putting the baby's safety and the mother's life in jeopardy. Child marriage also increases the risk of partner abuse, and if an undesired pregnancy happens, it is more likely to be concealed, resulting in inadequate pregnancy care and health services [9], [10]. 
Psychological effects were also discovered in all research areas where partners were not psychologically prepared to take on new duties and deal with household issues, which frequently resulted in regret for missing school and adolescence. Domestic violence, especially among young females in marriage, has the potential to produce trauma to the point of deat [11].

Maternal mortality, according to research by Abdi, women aged less than 20 years can be at risk for death 3 times. Apart from being too young, maternal mortality can also occur due to a lack of use of contraceptives. When someone is lacking in knowledge of contraception and economic conditions, there will be unmet need for family planning in couples of childbearing ages [12].

Early Childhood Pregnancy with Premature Labor. The biological mechanism of the increase in the incidence of preterm labor in adolescent mothers is explained as follows, namely that blood circulation to the cervix and uterus in adolescents is generally imperfect and this results in reduced nutrition for pregnant adolescent fetuses. Likewise, less blood circulation in the genital tract causes an increase in infection which will cause preterm labor to increase [13], [14].

Cervical cancer is a malignant tumor most often found in the female reproductive system. Most cases are squamous epithelial carcinoma, local growth tumors, generally invade the parametrium tissue and pelvic organs and spread to the lymph nodes of the pelvic cavity. Cervical cancer is four times more likely in 20-year-old marriages than in 20 -year-old marriages [15].

\section{Conslusion}

In Indonesia, the provinces with the highest percentage of teenage marriage aged 10-14 years were Central Java (52.1\%), South Kalimantan (9\%), West Java (7.5\%), East Kalimantan and Central Kalimantan respectively $(7 \%)$, and Banten $(6.5 \%)$ while the provinces with the highest percentage of cases of teenage marriage aged 15-19 years were Central Kalimantan (52.1\%), West Java (50.2\%), South Kalimantan (48.4\%), Bangka Belitung (47.9\%), and Central Sulawesi. This were due to differences in knowledge, education, economy and culture factors in various regions in Indonesia.

Prior to the Covid-19 pandemic, it was estimated that around 100 million children were undergoing forced marriages for the next 10 years. Over the next decade, there will be more than 10 million new girls who have the potential to become brides at a very young age. Closing schools, declining economic conditions and hampering assistance for affected families increase the potential for girls to become wives before they reach adulthood in 2030 .

\section{References}

[1] BKKBN, BPS, Kementerian Kesehatan, dan ICF International. Survei Demografi dan Kesehatan Indonesia. 2012.

[2] BKKBN, BPS, Kementerian Kesehatan, dan ICF International. Survei Demografi dan Kesehatan Indonesia. 2017.

[3] Handayani, O. W. K., Wiranti, I., Raharjo, B. B., \& Nugroho, E. The Reproduction Health Behavior of High School Teenagers in Semarang, Indonesia. The Open Public Health Journal. 2019, 12(1).

[4] Nugroho, E., Shaluhiyah, Z., Purnami, C. T., \& Kristawansari. Counseling Model Development Based on Analysis of Unwanted Pregnancy Case in Teenagers. KEMAS: Jurnal Kesehatan Masyarakat. 2017, 13(1): 137-144. 
[5] James B. Weaver, Darren Mays, Stephanie S. Weaver, Gary L Hopkins, Dogan Eroglu \& Jay M Bernhardt. Health Information; Seeking Behaviour, Health Indicators and Health Risk. American Journal of Public Health. 100 (8): 2010, 1520-1525.

[6] Nour, N. M. Child Marriage: A Silent Health and Human Right Issue. Women's Health in the Developing World. 2019, 2(1): 51-56

[7] Nugroho, E., Nisa, A. A., Rahayu, F. D., Hermawan, D. Y., \& Najib,. Development of CommunityBased Health Communication Models in the Early Marriage Partners. 2019, In 5th International Conference on Physical Education, Sport, and Health (ACPES 19). Atlantis Press.

[8] Raharjo, B. B., Nugroho, E., Cahyati, W. H., Najib, N., \& Ainun, A. Proximate Determinant of Adolescents Fertility in Central Java. 2019, KEMAS: Jurnal Kesehatan Masyarakat, 15(1).

[9] Skiles MP, Cunningham M, Inglis A, Wikes B, Hatch B, Bock A, Barden-O Fallon. The effect of access to contraceptive services on injectable use and demand for family planning in Malawi. Int Perspect Sex Reprod Health. 2015, 41(1):20-30

[10] Tait AR, Voepel-Lewis T, Levine R. Using digital multimedia to improve parents' and children's understanding of clinical trials. BMJ Journal Archives of Disease in Childhood. 2015, 100:589-593.

[11] United Nations Office of the High Commissioner for Human Rights (OHCHR). Recommendations for Action Against Child and Forced Marriages [Internet]. UNICEF/UN05222/Dragaj. 2017.

[12] United Nations. Convention on Consent to Marriage, Minimum Age for Marriage and Registration of Marriages. 1962.

[13] Yu SH, Mason J, Crum J, Cappa C, Hotchkiss DR. Differential effects of young maternal age on child growth. Glob Health Action. 2016;9(1):31171. doi: 10.3402/gha.v9.31171.

[14] Nasrullah M, Muazzam S, Bhutta ZA, Raj A. Girl child marriage and its effect on fertility in Pakistan: findings from Pakistan demographic and health survey, 2006-2007. Matern Child Health J. 2014;18(3):534-543. doi: 10.1007/s10995-013-1269-y.

[15] Cader AA. Ending child, early, and forced marriage: SRHR as Central to the Solution. Asian-Pacific Resource \& Research Centre for Women (ARROW). 2017:40. ISBN: 978-967-0339-38-2. 